\title{
IMPEACHMENT AND RECALL OF LEGISLATORS IN NIGERIA AND UNITED STATES OF AMERICA
}

\begin{abstract}
Ilias B. Lawal*
The legislature, variously called the National Assembly, the Congress or the Parliament, plays a critical in any democratic dispensation. In addition to its law-making functions, the legislature also serves as a check on other arms of government through its oversight functions. These enormous responsibilities constitutionally imposed on the legislature are susceptible to being abused. Some of the ways by which the Nigerian Constitution seeks to curb such a negative tendency are the provisions on recall of legislators and forfeiture of legislative seats. This paper makes a comparative analysis of the constitutional provisions on recall of legislators and forfeiture of legislative seats in Nigeria and United States of America and offers suggestions for improvement.
\end{abstract}

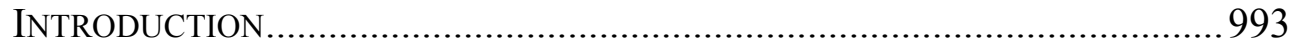

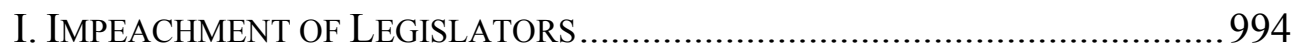

II. RECALL OF LEGISLATORS ........................................................... 998

III. RECALL OF LAWMAKERS IN AMERICA ............................................999

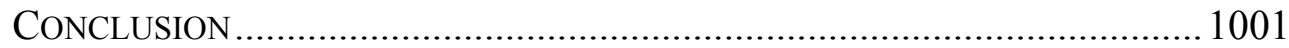

\section{INTRODUCTION}

In any democracy, nascent or advanced, legislatures play a vital role in the socioeconomic well being of the people. Apart from their law-making function for which they are highly reputed, ${ }^{1}$ they also play an important role in policy formulation and execution ${ }^{2}$ thorough the legislative investigation committees $^{3}$ and confirmation of appointments made by the executive. ${ }^{4}$ The legislature also performs some judicial functions. In most countries, the decision of the legislature on removal of its own members is highly respected. ${ }^{5}$ Similarly, in Nigeria, no legislative proceedings relating to the

\footnotetext{
${ }^{*}$ Ilias B. Lawal, LL.B (Hons) (Ibadan), LL.M (Ife) BL; Senior Lecturer and Ag. Head, Department of Public Law, Faculty of Law, University of Ibadan. The author's research interest includes Constitutional Law, Human Rights and Islamic Law.

${ }^{1}$ Section 4 of the 1999 Nigerian Constitution vests the National Assembly with the power to make laws for peace order and good governance of the country; see also Article 1, Section 1 of the United States Constitution.

${ }^{2}$ The legislative debates on the annual appropriation bills before their passage can substantially influence policy formulation and execution.

${ }^{3}$ See Section 88 of the 1999 Constitution.

${ }^{4}$ See Sections 147 and 231 of the 1999 Constitution on the appointment of Minister and the Chief Justice of the Federation, respectively.

${ }^{5}$ See Oloyo v. Alegbe (unreported), FCA/B/6/82 of 1/8/82.
} 
removal of President or Governor "shall be entertained in any court". 6 To underscore the trust and confidence, the 1999 Nigerian Constitution has in the law-makers, the legislature is empowered to conduct investigation into the affairs of any person, authority, ministry or government department charged or intended to be charged with the duty and responsibility for disbursing or administering moneys appropriated by the legislature with a view of exposing corruption, inefficiency or waste in the execution or administration of laws within its legislative competence and in the disbursement or administration of funds by it. $^{7}$

In order to prevent the abuse and misuse of the enormous powers of legislature and others act volatile of the Constitution, the 1999 Nigerian Constitution makes elaborate provisions for recall of legislators and conditions under which legislators may forfeit their seats in the legislative house. The latter provision is loosely called "impeachment".

\section{IMPEACHMENT OF LEGISLATORS}

To impeach literally means "to challenge the credibility of" or "to accuse". ${ }^{8}$ According to the Black's Law Dictionary, impeachment is the act (by legislature) calling for removal of a public official accomplished by presenting a written charge of the official's alleged misconduct. Impeachment originated in Britain where the House of Commons would present articles of impeachment to the House of the Lords' which then tried the case. ${ }^{10}$ To Eskine May, impeachments are reserved for extra-ordinary offences and extra-ordinary offenders. ${ }^{11}$ The last impeachments were those of Warren Hasitngs (1786-95), First Governor-General of India and Lord Melville (1806) but an unsuccessful attempt was made by Thomas C. Anstey to impeach Lord Palmerston in $1848 .^{12}$

In the United States of America, impeachment is the first step in the process specified in the Constitution for removing the President, Vice President or other government officials from office upon conviction of

\footnotetext{
${ }^{6}$ See Sections 143 (10) and 188 (10) of the 1999 Constitution.

${ }^{7}$ For the nature and extent of the legislative power of investigation, see Atilola B., Scope and Limits of Legislative Powers of Investigation: El-Rufai v. House of Representatives Revisted, 1(2) Legislative Practice ReView 1-14 (2009).

${ }^{8}$ Curzon L. B., Dictionary of LAW 20 (England: Pearson Education Ltd. 2002).

${ }^{9}$ BLACK's LAW DiCTIONARY 753 (6th ed.).

${ }^{10} 11$ ACADEMIC AMERICAN ENCYClOPEDIA 6 (USA: Grotier Inc. 1990).

${ }^{11}$ May Erskine, Ttearise on Law Privilegges, Proceedings and USage of Parliament 734 (England: Butterworths 1964).

1212 ENCYCLOPEDIA BRITANNICA 118 (London 2003).
} 
"treason, bribery or other high crimes and misdemeanors". ${ }^{13}$ Impeachment resolutions made by the members of House of Representatives are turned over to the House Judiciary Committee which decides whether the resolution and its allegations of wrong doing by the public official involved merit a referral to the full House for a vote on launching a formal impeachment inquiry. In Nigeria, the first complete effort to introduce impeachment as a sanction against erring public officers was in the 1979 Constitution. ${ }^{14}$ The provision was virtually repeated in both the 1989 and 1999 Constitution. ${ }^{15}$ The word "impeachment" is not used in any of these provisions. Rather, the Constitution provides for the removal of President, Vice President, Governor and Deputy Governor when the holder of any of these offices is guilty of gross misconduct ${ }^{16}$ in the performance of the functions of this office. ${ }^{17}$

It is noted worthy that, the Nigerian Constitutions does not expressly provide for the impeachments of members of the legislature; it however makes provisions for circumstances under which the presiding officers of the legislative houses and other members can vacate their officers or forfeit their seats respectively. ${ }^{18}$ By Section 50 of the 1999 Constitution, the President or Deputy President of the Senate and the Speaker of the House of Representative shall vacate his office if he ceases to be a member of the Senate or of the House of Representatives "otherwise than by reason of a distribution of the house or the House of Representatives"; ${ }^{9}$ or when the House of which he was a member first sits after any dissolution of that House, ${ }^{20}$ or if he is removed from office by a resolution of the Senate or of the House of Representatives, by the votes of two-thirds of majority of the members of that House. ${ }^{21}$

Vacation of office by the presiding officers of the National Assembly on grounds of cessation of membership or dissolution of either House of the National Assembly does not seem to cast a pall on the integrity of the

\footnotetext{
${ }^{13}$ Available at http://www. Historyplace.com/united states/impeachments/retrieved (last visited October 23, 2011).

${ }^{14}$ Ibid.

${ }^{15}$ See Sections 132 and 170 of the 1979 Constitution.

${ }^{16}$ Sections 143 and 188 of the 1999 Constitution.

${ }^{17}$ Section 143 (11) of the 1999 Constitution defines "gross misconduct" as a "grave violation of the provisions of this Constitution or a misconduct of such nature as amounts in the opinion of the National Assembly to gross misconduct".

${ }^{18}$ See Section 50 of the 1999 Constitution.

${ }^{19}$ See Section 50(2) (a) of the 1999 Constitution.

${ }^{20}$ See Section 50(2) (b) of the 1999 Constitution.

${ }^{21}$ See Section 50(2) (c) of the 1999 Constitution; see also Sections 92 (a) (b) and (c) in respect of Speakers and Deputy Speakers of Houses of Assembly.
} 
officer concerned. However, vacation of office on ground of removal by two-third majority of either House seems to impeach or malign the character of such an officer given the fact that, the presiding officers are usually elected by a simple majority of the members. Hence the provision of Section 50(2) (c) of the 1999 Constitution on removal of the presiding officers is usually regarded as impeachment of the officers concerned even though no such word is specifically used in the Constitution. ${ }^{22}$

Furthermore, Section 68 of the Constitution makes elaborate provisions for circumstances, the that may lead to forfeiture of seat by any member of the National Assembly. These include: when such a member becomes a member of another legislative house ${ }^{23}$ the occurrence of circumstances that would cause him to be disqualified for elections as a member of the National Assembly of the was not already a member; ${ }^{24}$ if the ceases to be a Nigerian citizen; ${ }^{25}$ if it becomes President, Vice President, Governor, Deputy Governor or a Minister of the Government of the Federation or Commissioner in a State, or a Special Adviser; ${ }^{26}$ if he becomes a member of a commission or any other statutory body; ${ }^{27}$ if he absent without just cause ${ }^{28}$ from meetings of the House of which he is a member for more than one-third of the total number of days during which the house meets in any one year; ${ }^{29}$ if the becomes an member of another political party other than the one that sponsored his election before the expiration of the period for which the House was elected, ${ }^{30}$ provided that, his membership of the latter political party is not as a result of a division in the political of he was previously a member or a merger of two or more political parties or factions by one of which he was previously sponsored; ${ }^{31}$ and if he is recalled in compliance with Section 69 of the Constitution. ${ }^{32}$ By Section 68(2), upon presentation of satisfactory evidence to the house concerned that, any of the above provisions has become applicable in respect of any member the

\footnotetext{
${ }^{22}$ For a critique of this provision, see AKANDE J. O., INTRODUCTION TO THE 1999 CONSTITUTION 131132 (Lagos: MIJ Publisher 2000).

${ }^{23}$ Section 68(1) (a) of 1999 Constitution.

${ }^{24}$ Section 68(1) (b) of 1999 Constitution.

${ }^{25}$ Section 68(1) (c) of 1999 Constitution.

${ }^{26}$ Section 68(1) (d) of 1999 Constitution.

${ }^{27}$ Section 68(1) (e) of 1999 Constitution.

${ }^{28}$ Section 68(3) of 1999 Constitution provides that: "a member of the Senate or of the House of Representative shall be deemed to be absent without just cause from a meeting of the House of which he is a member, unless the person presiding certifies in writing that he is satisfied that, the absence of the member from the meeting was for a just cause".

${ }^{29}$ Section 68(1) (f) of 1999 Constitution.

${ }^{30}$ Section 68(1) (g) of 1999 Constitution.

${ }^{31}$ See the proviso to Section 68(1) (g) of the 1999 constitution.

${ }^{32}$ Section 68(h) of 1999 Constitution.
} 
presiding officers of the respective houses "shall give effect" to the provision of Section $68(1)$ of the Constitution. ${ }^{33}$

Of all the conditions that would necessitate forfeiture of seats by members of the legislature, only two seem to impact negatively on the character of the law maker concerned. These are being absent without just because from the meeting of a legislative House for more than one-third of the total days of meeting and defecting to another party different from the one that sponsored their election before the expiration of their legislative term. In Oloyo $v$ Alegbe, ${ }^{34}$ one of the issues for determination was the competence of the presiding officers of a legislative House, to declare a member's seat vacant for being absent from meetings without just cause for more than one-third of the total number of days during which the House meets in any one year.

It was argued that, only the High Court could declare a member's seat vacant, and that the presiding officers could only refer the alleged contravention of the constitution to the High Court for determination. The argument was accepted by the High Court of Bendel State. On appeal, the Federal Court of Appeal held that, the enforcement of the constitutional provision was the responsibility of the House or the Speaker in the first instance. ${ }^{35}$ The court further observed that, the fact the constitution had given the High Court special jurisdiction to deal with the matter did not mean that, the House or the Speaker thereof must fold their arms and allow a breakdown of discipline in complete disregard of the provisions of the Constitution. ${ }^{36}$ The Court of Appeal's decision was subsequently affirmed by the Supreme Court by a majority of 5 to $2 .^{37}$

On the issue of legislators who leave the party that sponsored their election for another party before the completion of their legislative tenure, it has been observed of that, the constitutional sanction forfeiture of legislative seat is to deter political flirtation or carpet crossing, and check legislators who may be tempted to leave their party to gain political office or some political advantage. ${ }^{38}$ There however seems to be a lacuna in the

\footnotetext{
${ }^{33}$ This means that, the presiding officer shall declare the seat of such a member, vacant, see Sections 109 (1) and (2) in respect of the state assemblies.

${ }^{34} 3$ NCLR 647 (1982).

${ }^{35}$ Alegbe v. Oloyo, FCA/B/61/82; see also Fajinmi v. The Speaker, Western Region House of Assembly (1962) I all NLR 205, Obiv Waziri (1961) 1 ALL NLR 37. Contrast with the case of Usman v. Kaduna House of Assembly and Others (2007) 11 NWLR 265 (Part 1204).

${ }^{36}$ Alegbe v. Oloyo, Ibid at 17-18.

${ }^{37}$ For a critique of this case, see Nwabueze B. O., Nigeria's Presidential Constitution London 164-169 (Longman 1985).

${ }^{38}$ Ebeku K. S. A., Nigeria's New Constitution for the Third Republic: An Overview, 5(3) AfRICAN JOURNAL OF INTERNATIONAL AND COMPARATIVE LAW 596 (1993).
} 
constitutional provision. According to Ebeku, the provision does not cover a legislator who is expelled by his party for anti-party activities. This can be contrasted with the positions in Namibia where members of the legislature lose their seat if their political party informs the Speaker that, they are no longer members of the party, which could be as a result of expulsion. ${ }^{39}$

\section{RECALL OF LEGISLATORS}

One of the innovations in the 1999 Constitution aimed at curing the excess of parliamentarians is Section 69 of the constitution which provides that, a member of the National Assembly may be recalled if:

“(a) There is presented to the Chairman of the Independent National Electoral Commission, a petition in that behalf signed by one-half of the persons registered in that member's constituency, alleging their loss of confidence in that member, and which signatures are duly verified by the Independent National Electoral Commission;

(b) The petition is thereafter, in a referendum conducted by the independent national electoral commission within ninety days of receipt of the petition, approved by a simple majority of the votes of the persons registered to vote in that member's constituency." 40

According to the Political Bureau, one of the reasons for the introduction of the power to recall was to establish in a permanent manner "a culture of consultation and reciprocal control law making and the use of power and privileges" ${ }^{41}$. Furthermore, it was based on the belief that, Nigerians have an idea of the goals of nationhood and the objectives of representation. It is this idea of conception which determines the depth of their faith in popular democracy and the nature of political judgment they form on the behaviour of their elected representatives. ${ }^{42}$

Before the amendment of the 1999 Nigerian Constitution in 2010, the verification of signatures of voters in the legislator's constituency was absent; the requirement was introduced by the Constitution of the Federal Republic of Nigeria (First Alteration) Act $2010 .{ }^{43}$ On the face of it, the amendment looks innocent, and well intended; however, the probability of its being abused by some corrupt officers of the Independent National Electoral Commission is very high, as it seems to further complicate the

\footnotetext{
${ }^{39}$ Cottrel J., The Constitution of Namibia: An Overview, JournAL OF AFricAn LAW 56-59 (1991).

${ }^{40}$ See Section 110 in respect of the state legislators.

${ }^{41}$ Report of Political Bureau 1987141 (Lagos: Federal Government Printers 1987).

${ }^{42}$ Ibid.

${ }^{43}$ It was passed by the Senate on June 2, 2010, and by House of Representatives on June 3, 2010. President Goodluck Jonathan signed it into law on January 10, 2011.
} 
process of recall. The modality for the verification of voters' signatures might also be deliberately made burdensome in order to frustrate the processes. It is therefore suggested that, the country should revert to the old provision without any need for verification of voters' signatures; or in the alternative, only people of impeccable character should be employed by the Independent National Electoral Commission, while any staff of the commission found to have been compromised should be severely dealt with. It is however surprising that, since the beginning of the Fourth Republic, more than a decade ago, the provision on recall has not been successfully invoked; there have been threats of its invocation. ${ }^{44}$ Of equal importance is the issue of accurate voters' register by which the relevant members of the constituency can be identified. It has also been observed that, the different controversies that have attended our several attempts at compiling voters' register illustrate how problematic the recall process can be. ${ }^{45}$ So also can be process be devilled by fraud, victimization and undue influence in the process of setting the machinery in motion. ${ }^{46}$ The consequence of recall to the legislative house where a legislator has been recalled is that, it creates a vacancy in the house. Consequently, a fresh election will be conducted in order to fill the vacancy, ${ }^{47}$

\section{RECALL OF LAWMAKERS IN AMERICA}

The issue of recall of parliamentarians is also very controversial in the United States of America, with different legal considerations governing it at the state and federal levels. In some states, states legislators or other state or local elected officials may be removed from office before the expiration of their terms not only be action of the legislature itself through an expulsion (or for executive officers, through an "impeachment" and conviction by the legislature), but also by voters through a "recall" election procedure. ${ }^{48} \mathrm{On}$ the other hand, the United States Constitution does not provide for the recall of United States Officials such as United States Senators, Representatives to

\footnotetext{
${ }^{44}$ For example, on August 27, 2005, the Speaker of Plateau State House of Assembly, Simon Lalong, survived the first recall attempt in Nigeria. Ten out of the eleven wards in his local government voted against the referendum.

${ }^{45}$ Guobadia D. A., The Legislature and Good Governance under the 1999 Constitution, IsSUES IN THE 1999 Constitution 66-67 (Ayua I. A., Guobadia, D. A., \& Odekunle, A. O. eds., Lagos: NIALS 2002).

${ }^{46}$ Ibid at 67.

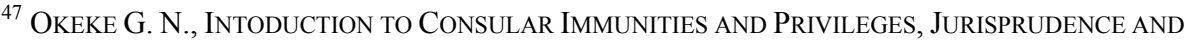
Constitutional Law 228-229 (Uwani-Enugu: Nolix Educational Publication 2010).

${ }^{48}$ Theodore M., State and Local Government Politics and Processes 90-93 (U.S.A: Charles Scribber and Sons 1996).
} 
Congress or the President or Vice President of the United States. ${ }^{49}$ Therefore, no United States Senator or member of House of representative has ever been recalled in the history of the country. In 1807, a Senate Committee examining the question of the Senate's duty to expel a member noted, among other things, that the constitution had set out numerous provisions, qualifications and requirements for members of Congress to prevent conflict of interest, and to assure a certain degree of fealty to constituents but did not a give a member's constituency the authority to recall such a member. ${ }^{50}$

Although the Untied States Supreme court has not directly addressed the subject of recall of members of Congress, there are other judicial decisions to the effect that, the right to remove a member of Congress, before the expiration of his term of office rests with each House of Congress as expressly delegated in the expulsion clause of the United States Constitution, and not in the entire Congress as a whole, nor in the State legislatures through the enactment of recall provisions. ${ }^{51}$ Similarly, the United States Supreme Court held in U.S. Term Limits, Inc. v. Thorton, ${ }^{52}$ that the authority of the individual sates under Article 1, paragraph 4, clause 1 , is not a broad authority for an individual state to substantially change the qualifications, length or number of terms of federal officials established within the constitution. With respect to the Tenth Amendment and the "reserved" authority of the states the United States Supreme Court held that, the determination of the qualification and terms for federal offices, created within the United States Constitution was not part of the original powers of sovereignty that, the Tenth Amendment reserved to the States. ${ }^{53}$

The import of the foregoing analysis is that, unlike what obtains under the Nigerians Constitution where both the members of the National Assembly and the states' Houses of Assembly are recallable by members of their constituency, only members of the state legislatures can be recalled by the members of their constituencies under the United States Constitution. The members of the Congress are not subject to the recall enactments in the states since their terms and qualifications of office for federal officers are prescribed by the United States Constitution, and not by those of the individual component states. Such officers can only be removed by the

\footnotetext{
49 See Masknell J., ReCall of Legislators and the Removal of Members of Congress from OFFICE Available at http://www.fas.org/sgp/crs/misc/RL30016.pdf (last visited October 1, 2011).

${ }^{50}$ Ibid.

${ }^{51}$ Burton v. United States, 202 US, 369.

${ }^{52}$ U.S. Term Limits, Inc. v. Thorton, 514 US, 810-862.

${ }^{53}$ Ibid at 802; see also Garcia v. San Antonio, Metropoitan Transit Authority 469 US 528, 549 (1985); New York v. United States, 505 US 144, 155-156 (1992).
} 
expulsion clause of the United States Constitution.

\section{CONCLUSION}

Constitutional provisions on impeachment and recall of public officers are enshrined to strike a just balance between immunity, enjoyed by some public officers and abuse of powers or offices held by them. Expectedly the process is very cumbersome, anachronistic and time-consuming. ${ }^{54}$ While the Nigerian Constitution has copious provisions on the impeachment and removal of the some members of the executive, ${ }^{55}$ it seems not to have any provision on impeachment of members legislature. It only has some provisions on how some presiding officers of the legislature could be relieved of their offices; ${ }^{56}$ and how members of the legislature could forfeit their seats. ${ }^{57}$ These provisions are not as detailed as the impeachment provisions of the chief executives. On the other hand, the provisions on recall of legislators are more specific and more detailed. While removal or expulsion of legislators is an internal authority of legislative bodies pursuant to their power to regulate their internal proceedings, and exercise authority over tier members, recall is a special process outside the legislature itself, exercised at the instance of the members for their constituency expressing their loss of confidence in their legislative representatives. The impeachment and recall clauses are meant to make the legislators to be alive to their responsibilities and to confirm that, sovereignty really belongs to the people. $^{58}$

It is however suggested that, these two provisions should be sparingly used in only deserving cases and should never be used as instruments of witch-hunting or character assassination. On their own part, the members of the Independent National Electoral Commission should not use the recent amendment in the recall provision, requiring the verification of the signatures of registered voters in the members' constituency to corruptly enrich themselves and frustrate an otherwise genuine recall process.

\footnotetext{
${ }^{54}$ This is because of the diverse interests and considerations involved.

${ }^{55}$ See Sections 143 and 188 of the 1999 Constitution.

${ }^{56}$ Section 50 of 1999 Constitution.

${ }^{57}$ Section 68 of 1999 Constitution.

${ }^{58}$ Section 14(2) of the 1999 Constitution.
} 